\title{
EDITORIAL In memoriam, Professor Marcio Versiani
}

Antonio E. Nardi', João Romildo Bueno', José Carlos Appolinario

One of the wisest and most elegant Brazilian psychiatrist left us recently. Professor Versiani is no longer among us, but his teachings and publications will always be with us. An excellent teacher never dies, he just cannot give more lectures.

Everyone who knew and learned from Professor Versiani recognized in him the unique intelligence, his sagacious mood, and the wisdom of a great teacher. His publications and conferences have spread to the scientific world long before the internet. During his very productive career he was interested in a wide range of psychiatric conditions. He published more than 170 peer-reviewed papers. Of note, he has leaded some seminal pharmacological studies, with focus on the pharmacotherapy of social phobia ${ }^{1,2}$, panic disorder ${ }^{3}$, and depressive disorders ${ }^{4,5}$. Those publications have had significant and far reaching international impact and are among the most cited Brazilian works considering all sciences. Professor's Versiani international visibility is also

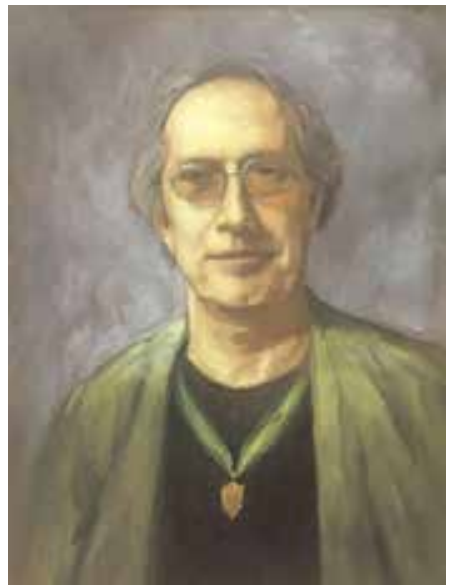

8/10/1947-4/12/2017 Professor Marcio Valadares Versiani Caldeira, MD, PhD Photograph by A.E. Nardi from an oil painting (M. Duprat, 1998) collection of the Institute of Psychiatry, Federal University of Rio de Janeiro, Brazil. Reprinted with permission. evident in the contributions that he has made to important clinical guidelines and consensus such as the Guidelines for Biological Treatment of Unipolar Depressive Disorders in Primary Care of the World Federation of Societies of Biological Psychiatry and, a Consensus Statement about Antidepressant and the Risk of Suicidality of the World Psychiatric Association ${ }^{7}$.

Professor Versiani was born on October 8, 1947 in Belo Horizonte city, at the State of Minas Gerais, Brazil. He graduated in Medicine from the Federal University of Minas Gerais, and master's degree and doctorate with brilliance in the Institute of Psychiatry of the Federal University of Rio de Janeiro. He was approved in a public contest for Full Professor of Psychiatry at the Faculty of Medicine of the Federal University of Rio de Janeiro in 1998. He was the founder and coordinator of the Anxiety and Depression Program of the same Institute for more than 30 years. This research Program was a very fruitful clinical psychiatry institution leading many important trials in psychopharmacology and producing a vast and productive generation of researchers and clinical psychiatrists.

1 Institute of Psychiatry, Federal University of Rio de Janeiro.

DOI: 10.1590/0047-2085000000176

Address to correspondence: Antonio E. Nardi, MD, PhD Institute of Psychiatry

Federal University of Rio de Janeiro

R. Visconde de Pirajá, 407/702

22410-003 - Rio de Janeiro, RJ, Brazil

Telefone: +55 (21) 2521-6147

Telefax: +55 (21) 2523-6839

E-mail: antonioenardi@gmail.com 
Professor Versiani was editor-in-chief of the Jornal Brasileiro de Psiquiatria for many years, Director of the University's Institute of Psychiatry (2003-2009), member of several national and international psychiatric societies. Most of all, he was a good fellow, always ready to guide young psychiatrists, and beloved by his patients. We all miss him very much.

\section{REFERENCES}

1. Versiani M, Nardi AE, Mundim FD, Alves AB, Liebowitz MR, Amrein R. Pharmacotherapy of social phobia. A controlled study with moclobemide and phenelzine. Br J Psychiatry. 1992;161:353-60.

2. Versiani M, Mundim FD, Nardi AE, Liebowitz MR. Tranylcypromine in social phobia. J Clin Psychopharmacol. 1988;8(4):279-83.
3. Versiani M, Cassano G, Perugi G, Benedetti A, Mastalli L, Nardi A, et al. Reboxetine, a selective norepinephrine reuptake inhibitor, is an effective and well-tolerated treatment for panic disorder. J Clin Psychiatry. 2002;63(1):31-7.

4. Versiani M, Ontiveros A, Mazzotti G, Ospina J, Dávila J, Mata S, et al. Fluoxetine versus amitriptyline in the treatment of major depression with associated anxiety (anxious depression): a double-blind comparison. Int Clin Psychopharmacol. 1999;14(6):321-7.

5. Versiani M, Amrein R, Stabl M. Moclobemide and imipramine in chronic depression (dysthymia): an international double-blind, placebo-controlled trial. International Collaborative Study Group. Int Clin Psychopharmacol. 1997;12(4):183-93.

6. Bauer M, Bschor T, Pfennig A, Whybrow PC, Angst J, Versiani M, et al.; WFSBP Task Force on Unipolar Depressive Disorders. World Federation of Societies of Biological Psychiatry (WFSBP) Guidelines for Biological Treatment of Unipolar Depressive Disorders in Primary Care. World J Biol Psychiatry. 2007;8(2):67-104.

7. Möller HJ, Baldwin DS, Goodwin G, Kasper S, Okasha A, Stein DJ, et al.; WPA Section on Pharmacopsychiatry. Do SSRIs or antidepressants in general increase suicidality? WPA Section on Pharmacopsychiatry: consensus statement. Eur Arch Psychiatry Clin Neurosci. 2008;258 Suppl 3:3-23. 